\title{
Small Modular Reactors: Safety and Economic Indicators, Perspectives of their Deployment into Unified Power Grid of Ukraine
}

Keywords:

small modular reactors, safety and economic indicators, unified power grid, low-carbon energy sources.

\begin{abstract}
Small modular reactors (SMRs) is a perspective technology for further development of nuclear energy sector, which has advantages as compared to the large nuclear reactors: less capital investments and implementation time, higher expected safety indicators, potential for power capacity maneuvering and as a result - better response to the needs of the energy market. The progress of light-water SMRs projects in the short term, as well as the overview of the SMR basic technical and economic indicators are represented in the paper. On the basis of NPC "Ukrenergo" data, the study of SMR advantages for the Unified Power Grid of Ukraine was conducted. Special focus was given to the maneuvering characteristics of SMRs and SMRs synergy with the renewable energy sources with changeable generation. The priority measures for SMRs implementation in Ukraine were formulated.
\end{abstract}

The today's challenges of technogenic and natural character define the need for fundamental and fast transformation of the global economy, which is suggested by two basic international agreements of 2015 - "Paris Climate Agreement" [1] and "Sustainable Development Goals by 2030" [2] adopted by the United Nations Organization, and ratified by Ukraine in 2016 [3] and 2019 [4], respectively.

The energy sector plays a key role in this transformation by supporting fulfilment of the majority of 17 goals in general, but at the same time it brings a negative impact onto the climate change. The energy production is the main contributor into the greenhouse gas emissions (about $40 \%$ of global $\mathrm{CO}_{2}$ emissions [5]), which results in the global climate change [6]. Therefore, review of the energy structure and transition to the low-carbon energy sources, along with the increase of general energy production to meet the needs of the consumers, is the primary task to ensure sustainable development in the world in general and in Ukraine in particular.

The dynamics of carbon dioxide emissions by the energy production facilities is presented in Fig. 1 [7].
Short-term reduction of $\mathrm{CO}_{2}$ emissions caused by the global crisis of different nature (including epidemiological crisis at the beginning of 2020, which continues at the time of paper preparation) do not change the general upward trend.

The nuclear power industry is an integral part of transformation of the global energy system. The types of greenhouse gases emitted by the power facilities are equitable with the corresponding indicators of renewable energy sources (Fig. 2 based on data [8]), which reasonably refer the nuclear power industry to low-carbon energy sources at the level of solar, wind and hydro power industry.

The necessary condition of achieving the climate goals, which lies in preventing the average global temperature increase for not more than $2{ }^{\circ} \mathrm{C}$ as compared to the pre-industrial level [1], is to limit the level of $\mathrm{CO}_{2}$ emissions by the value of $50 \mathrm{~g} / \mathrm{kWh}$ [5]. As Fig. 2 demonstrates, the above indicated limitation is possible to achieve only by making a transition to the low-carbon energy sources, including the nuclear power industry.

(C) V. V. Demianiuk, 2020 


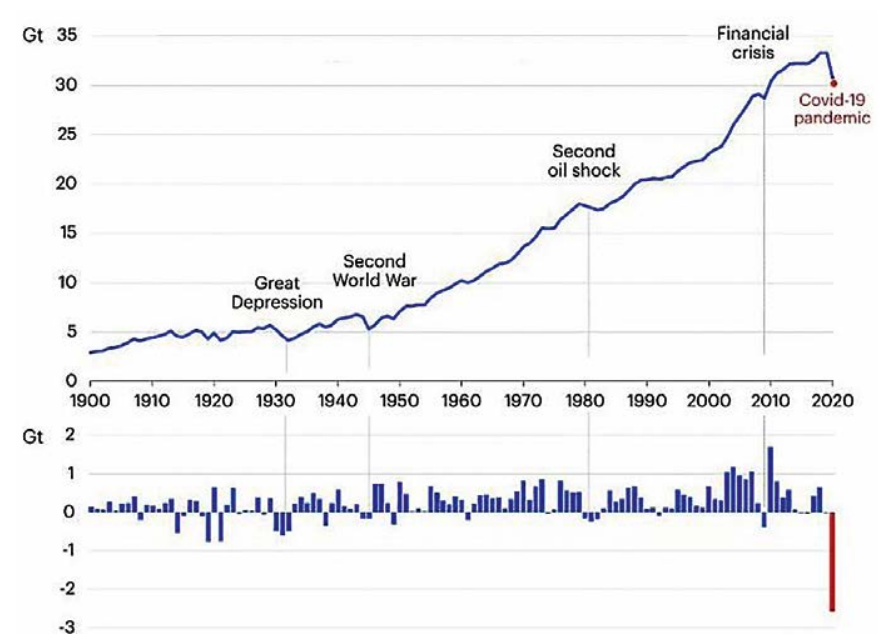

Fig. 1. Carbon dioxide emissions by power generating facilities, IEA [7]

In the context of climate aspects and limitation of $\mathrm{CO}_{2}$ emissions, the nuclear power industry certainly has the future for further development. With that, there are particular deterrent economic and social-political factors on the way of introducing the new nuclear energy facilities. The main one is great capital expenses and long construction time of new nuclear power plants (NPPs), which create investment risks and curb competitive ability of large reactors (electric power higher than $700 \mathrm{MW}$ ) at the liberalized energy markets without governmental support.

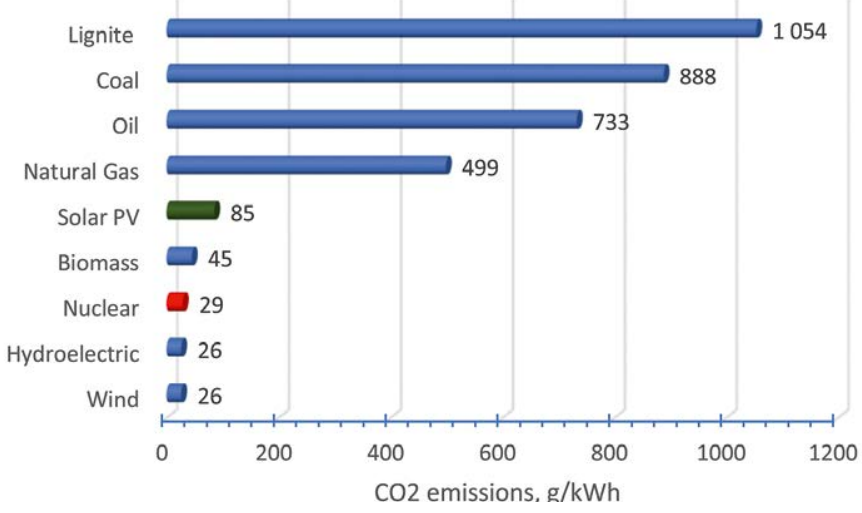

Fig. 2. Carbon dioxide emissions from different energy sources

Small modular reactors (SMRs) is a perspective technology for further nuclear energy development, which has advantages as compared to the large nuclear reactors: less capital investments and implementation period, higher expected safety indicators, potential for power maneuvering and as a result better compliance with the needs of modern energy market.
It can be assumed that the pilot implementation of the SMR technology will take place in the countries with the operating NPPs and effective national regulation system of nuclear and radiation safety. With that, the perspective market for SMRs are the countries, which just plan the development of nuclear energy field to optimize the consumption of carbon energy sources and which can use the SMR advantages ( $<300 \mathrm{MWe})$ for their energy systems.

Ukraine has launched the activity on analysis of the perspectives for implementation of SMR technology and achieved agreement on cooperation with the potential SMR suppliers in the short-term perspective, i.e. HOLTEC International (SMR-160 design) [9] and NuScale Power (NuScale design) [10].

From the point of view of modern unified power grid (UPG) of Ukraine, it is particularly pertinent to use the SMRs maneuvering capabilities. According to the report of NPC "Ukrenergo" [11]: the UPG of Ukraine was created for operation in essentially different conditions than those that it has to operate today. The most important factor in transformation of Ukrainian UPG as of today is to rapidly introduce the power stations with unguaranteed capacity using the renewables (RES), which do not go with the parallel introduction of regulated capacities that have relevant characteristics and volumes. It is necessary to implement more than $2 \mathrm{GW}$ of highly maneuvering generation capacities with quick start.

The existing infrastructure, vast experience in NPPs operation, competent regulatory body and highly skilled engineering personnel along with the needs of Ukrainian UPG in the maneuvering capacities - create necessary prerequisites for implementation of the SMR technologies in Ukraine. Taking into account the available engineering and technical potential, Ukraine can be not only a recipient of the SMR western technologies but also participate in the joint development and implementation of the SMR projects together with their suppliers, with localization of production in Ukraine and further export of the SMR designs and experience to the eastern markets. The above mentioned can be achieved by establishing the corresponding technological hub in Ukraine in cooperation with the international partners and with the governmental support.

This paper gives an overview of the basic safety and economic indicators of SMR technology, indicates the key economic parameters for development of the SMR investment attractiveness, presents the analysis of positive and negative factors that influence the SMR cost. Based on the data of NPC "Ukrenergo", the preliminary general study 
of the SMR perspectives for the Ukrainian UPG has been conducted. Special attention was paid to the SMRs' maneuvering characteristics and combination of SMRs and RES with variable generation. In addition, some proposals are provided to review the Concept of "green" energy transition of Ukraine by 2050 [12], addressing the role of nuclear energy field.

This paper is based on the international data and studies available to the public, which can be found in the list of references. Currently, no empirical information is available with regard to the SMRs, that is why the given data can be corrected along with experience gained on the SMR licensing and construction. The relevant licensing issues for the SMR technology are discussed in the paper [13] and are not repeated here.

\section{Safety and economic indicators of the SMR technology}

Rapid development of the SMR technology is conditioned by the energy market needs in the competitive low-carbon capacities with stable energy production against the delay and significant rising costs for implementation of the large reactors construction projects, which is also due to the increased safety requirements after the accident at Fukushima Daiichi NPP.

According to the optimistic assessments of the $\mathrm{Nu}-$ clear Energy Agency (NEA) of the Organization for Economic Cooperation and Development (OECD) [14], the part of SMRs by 2035 will constitute about $3 \%$ from the total installed capacity of nuclear energy in the world, which corresponds to the SMRs' total capacity of $21 \mathrm{GW}$.

Based on the results of SMR basic characteristics analysis in [13], the conclusion was made as for the advantages for implementation of the projects in Ukraine for SMRs that will use light water as a coolant and neutron moderator (light-water SMRs). The engineering solutions for light-water SMRs take into consideration the experience in operation of power units of NPPs with water-moderated water-cooled power reactors (WWERs). Table 1 provides the current status of implementation of the light-water SMRs, which can be potentially introduced in a short-term prospective (high-temperature gas-cooled SMRs (HTGR) and fast-breed reactor designs are not considered).

As it can be seen from the Table 1, the design process related to the SMR technologies is most actively conducted in the USA. Starting from 2012, the Office of Nuclear Energy of the U.S. Department of Energy (DOE) provides co-financing in the amount of $50-80 \%$ to the private companies for development of the SMRs. In 2019, the U.S.
Table 1. Status of implementation of the light-water SMRs, which can be potentially introduced in the short-term prospective (May, 2020) [20]

\begin{tabular}{|c|c|c|c|}
\hline \multirow{2}{*}{ SMR design } & \multicolumn{2}{|c|}{ Electric output } & \multirow{2}{*}{ Licensing status } \\
\hline & Module & $\mathrm{N}$ el (MW) & \\
\hline $\begin{array}{l}\text { CAREM-25 } \\
\text { (prototype) } \\
\text { Argentina }\end{array}$ & 1 & 27 & $\begin{array}{c}\text { Licensed in } \\
\text { Argentina, at the } \\
\text { construction phase }\end{array}$ \\
\hline $\begin{array}{c}\text { SMART } \\
\text { South Korea }\end{array}$ & 1 & 90 & Licensed in Korea \\
\hline $\begin{array}{l}\text { NuScale } \\
\text { USA }\end{array}$ & 12 & $12 \times 60$ & $\begin{array}{l}\text { Design certification } \\
\text { in the USA, } \\
\text { preliminary design } \\
\text { assessment in } \\
\text { Canada }\end{array}$ \\
\hline $\begin{array}{l}\text { SMR-160, LLC } \\
\text { (Holtec) } \\
\text { USA }\end{array}$ & 1 & 160 & $\begin{array}{l}\text { Preliminary } \\
\text { application } \\
\text { processing in } \\
\text { the USA and } \\
\text { preliminary design } \\
\text { assessment in } \\
\text { Canada }\end{array}$ \\
\hline $\begin{array}{l}\text { mPower } \\
\text { USA }\end{array}$ & 2 & $2 \times 180$ & $\begin{array}{l}\text { Preliminary } \\
\text { application } \\
\text { processing in the } \\
\text { USA }\end{array}$ \\
\hline $\begin{array}{l}\text { BWRX-300 } \\
\text { GE Hitachi } \\
\text { Nuclear } \\
\text { Energy } \\
\text { USA }\end{array}$ & 1 & 300 & $\begin{array}{l}\text { Preliminary } \\
\text { application } \\
\text { processing in the } \\
\text { USA }\end{array}$ \\
\hline $\begin{array}{c}\text { Westinghouse } \\
\text { SMR } \\
\text { Great Britain }\end{array}$ & 1 & 225 & $\begin{array}{l}\text { Information not } \\
\text { available }\end{array}$ \\
\hline
\end{tabular}

DOE launched a new SMR research program with a total budget of $100 \mathrm{M}$ dollars [15]. In particular, the financing has been provided for the following activities:

NuScale Power - NuScale SMR first-of-a-kind nuclear demonstration readiness project;

BWXT - Establishment of an integrated advanced manufacturing and data science driven paradigm for advanced reactor systems;

Columbia Basin Consulting Group, LLC - Conceptual engineering for a SMR power plant based on lead-bismuth fast reactor (LBFR) Technology;

Holtec International - Advancing and commercializing hybrid laser arc welding (hlaw) for nuclear vessel fabrication, including SMRs; 
Table 2. Key qualitative characteristics of different types of power generation [17]

\begin{tabular}{|c|c|c|c|c|c|}
\hline \multirow{2}{*}{ Characteristic } & \multicolumn{2}{|c|}{ Nuclear } & \multirow{2}{*}{ Coal } & \multirow{2}{*}{ Gas } & \multirow{2}{*}{ Wind and solar } \\
\hline & SMR & NPP & & & \\
\hline Investment level & High & Very high & Average & Low & Average-high \\
\hline Construction time & $2-4$ years & $4-10$ years & $4-5$ years & $2-3$ years & $0.5-2$ years \\
\hline Operation cost & Low & Low & Low-average & Low-average & Very low \\
\hline $\begin{array}{l}\text { Operational char- } \\
\text { acteristics }\end{array}$ & $\begin{array}{l}\text { Base and peak } \\
\text { modes, } \\
\text { high maneuvering }\end{array}$ & $\begin{array}{l}\text { Base mode, } \\
\text { medium } \\
\text { maneuvering }\end{array}$ & $\begin{array}{l}\text { Base mode, } \\
\text { average } \\
\text { maneuvering }\end{array}$ & $\begin{array}{l}\text { Peak mode, } \\
\text { high maneu- } \\
\text { vering }\end{array}$ & $\begin{array}{c}\text { Unstable mode, } \\
\text { dependence on changeable } \\
\text { weather conditions }\end{array}$ \\
\hline $\mathrm{CO}_{2}$ emissions & Low & Low & High-very high & Average & Low \\
\hline Key risks & $\begin{array}{c}\text { Regulatory } \\
\text { (licensing), } \\
\text { Absence of prac- } \\
\text { tical operational } \\
\text { experience }\end{array}$ & $\begin{array}{l}\text { Regulatory, com- } \\
\text { pliance to market } \\
\text { needs, acceptance } \\
\text { by population }\end{array}$ & $\begin{array}{l}\text { Ecological, } \\
\text { market }\end{array}$ & $\begin{array}{l}\text { Ecological, } \\
\text { market }\end{array}$ & $\begin{array}{c}\text { Change of price policy of } \\
\text { energy market }\end{array}$ \\
\hline Other peculiarities & $\begin{array}{l}\text { Low dependence } \\
\text { on fuel price }\end{array}$ & $\begin{array}{l}\text { Low dependence } \\
\text { on fuel price }\end{array}$ & $\begin{array}{l}\text { High } \\
\text { dependence on } \\
\text { fuel price }\end{array}$ & $\begin{array}{c}\text { High } \\
\text { dependence } \\
\text { on fuel price }\end{array}$ & $\begin{array}{c}\text { Connection costs, need in } \\
\text { compensating capacities, low } \\
\text { effectiveness }\end{array}$ \\
\hline
\end{tabular}

SMR, LLC - Integral and separate effects test program for the investigation and validation of passive safety system performance of SMRs.

The U.S. DOE allocated 230 M USD for 2020 financial year for implementation of the Advanced Reactor Demonstration Program, where $160 \mathrm{M}$ dollars were provided to co-fund the construction of two advanced reactors, which can start their operation in 5-7 years [16]. The U.S. Nuclear Regulatory Commission (NRC) plans to finish certification of NuScale SMR design in January 2012. In this case, the duration of the regulatory review of the NuScale safety justifying materials will constitute 46 months.

Considering the current status of the design efforts, experimental justification of the engineering decisions, as well as licensing of the SMR design, the most realistic for Ukraine in a short-term perspective is implementation of the light-water SMRs, designed in the USA, i.e. NuScale, SMR-160, mPower. Further on, the list of perspective designs can be reviewed and complemented with other SMR designs based on the technical and economic estimates and preparedness of the suppliers to produce modules and construct the SMRs.

The technical and economic indicators of the SMR technology are discussed further. Table 2 presents the results of the qualitative benchmark analysis of different types of electrical generation as per the key aspects. Hence, the SMRs have several qualitative advantages compared to other types of generation (coal, gas, wind and solar) and large reactors. However, they also tend to have high regulatory (licensing) risks and no practical experience in implementation.

In general, advantages of the SMRs against large reactors can be qualified by two aspects:

\section{Safety:}

advanced application of the passive systems (heat removal by natural processes without personnel intervention and need for power supply);

exclusion of possible occurrence of the particular groups of initiating events, peculiar for the NPP (e.g. loss of coolant accident);

smaller amount of radioactive materials, which can be released into atmosphere as a result of potential radioactive release;

smaller size of emergency planning zone (EPZ).

2. Economy:

less capital investments into construction;

possibility of stage-by-stage investment and power augmentation by installation of additional modules;

smaller project implementation time frame; 
market advantages due to maneuvering potential and creation of hybrid systems with renewable energy sources (RES);

lower expected cost for decommissioning;

development of the industry and creation of workplaces.

For general assessment of SMR's safety, two groups of qualitative indicators could be used:

probabilistic safety indicators: core damage frequency $(\mathrm{CDF})$ and large early release frequency (LERF/LRF);

EPZ.

Combination of these two indicators enables to make an integral assessment of the effectiveness of SMR solutions from the point of view of prevention of the accident occurrence, accident management and mitigation of the radioactive consequences. The size of the EPZ is a key parameter to identify the allowable distance of the SMR location from the settlements, which is important from standpoint of the possibility to use the SMRs to replace the coal power stations on the already existing sites.

The qualitative indicators of SMR safety and size of the emergency planning zone are presented in the Table 3. The indicated numeric values of CDF, LERF/LRF were provided by the suppliers of the SMR technology and are not confirmed by the results of peer review. Despite this limitation, it can be stated that the values of CDF, LERF/ LRF for SMRs will be no larger than $10^{-6}$ and $10^{-9}$ reactor per year, which is 2-3 orders less than the values of these indicators for operating NPPs, and meet the target values for new NPP designs established by [18]: $5 \cdot 10^{-6}$ and $10^{-7}$ reactor per year, respectively.

Considering the more advanced safety characteristics and smaller amount of radioactive materials in the SMR core (less potential for radioactive release), it is expected that no protection measures will be required for the population outside the SMR location site: iodine prophylaxis, shelter, evacuation (for instance, the size of EPZ for operating NPPs according to the U.S. NRC regulation is $16 \mathrm{~km}$, the size of emergency zone for Ukrainian NPPs is $30 \mathrm{~km}$ ).
The following basic indicators are applied to assess the economic and financial factors of the power generating facilities:

Overnight capital cost - capital costs, estimated with the assumption of overnight construction of the object at the current moment. This indicator does not take into account operational and other costs, changes of financial conditions during project implementation, electricity production. The overnight capital cost is calculated in USD/kW.

Levelised cost of electricity (LCOE) or Levelised unit of electricity cost (LUEC) - an average calculated prime cost of the electricity, generated during the entire life cycle of the power station. LCOE includes the capital costs, costs for operation and maintenance, costs for fuel and decommissioning. When calculating LCOE, only the funds of the owner/operator are taken into account, the funds of other market participants are not included (investments into the network, system balancing, etc.). The LCOE considers the amount of generated electricity and is calculated in USD/kWh.

Within the total NPP cost, the capital costs make about $60 \%$; costs for operation, including costs for nuclear fuel, make about $25 \%$; costs for decommissioning - about $15 \%$ (part of costs for decommissioning with a discount for 40-60 years of NPP operation is insignificant) [22].

Based on the results of statistical analysis in [22], the calculated values of the overnight capital cost for different types of energy generating capacities are presented in Table 4.

Here are positive and negative factors, which influence the SMR economic indicators [23]:

1. Economy of scale. SMR's capacity is considered to be the main negative factor, which influences the SMR's economy as compared to the large reactors. Based on individual conservative assessments, the overnight capital cost in USD/ $\mathrm{kW}$ for SMRs can be up to 50-70\% higher than for large reactors. However, these assessments use the assumptions for construction of SMRs and large reactors of one design

Table 3. Expected qualitative safety indicators of SMRs [19], [20] and size of the emergency EPZ

\begin{tabular}{|c|c|c|c|c|c|c|}
\hline Safety indicator & NuScale [21] & SMR-160 & mPower & $\begin{array}{c}\text { Westinghouse } \\
\text { SMR }\end{array}$ & SMART & $\begin{array}{c}\text { Operating NPPs } \\
\text { (III generation) }\end{array}$ \\
\hline $\begin{array}{c}\text { Core damage frequency } \\
\text { (CDF), reactor/year }\end{array}$ & $3.0 \cdot 10^{-10}$ & $<1 \cdot 10^{-8}$ & $<1 \cdot 10^{-8}$ & $<5 \cdot 10^{-8}$ & $2 \cdot 10^{-7}$ & $10^{-4} \div 10^{-5}$ \\
\hline $\begin{array}{c}\text { Large early release (LERF/ } \\
\text { LRF), reactor/year }\end{array}$ & $2.3 \cdot 10^{-11}$ & - & - & - & - & $10^{-5} \div 10^{-6}$ \\
\hline $\begin{array}{c}\text { Size of emergency plan- } \\
\text { ning zone (EPZ), km }\end{array}$ & \multicolumn{3}{|c|}{ The target for SMR designs is limitation of the emergency planning zone } \\
with the boundary of SMR site & $\begin{array}{c}16 \mathrm{~km} \text { (U.S. NRC } \\
\text { regulation) }\end{array}$ \\
\hline
\end{tabular}


Table 4. Overnight capital cost of different types of electricity generating capacities (median value)

\begin{tabular}{|l|c|}
\hline \multicolumn{1}{|c|}{ Technology } & $\begin{array}{c}\text { Overnight capital cost } \\
\text { construction, USD/kWe }\end{array}$ \\
\hline $\begin{array}{l}\text { Natural gas } \\
\text { (combined cycle gas turbines, } \\
\text { CCGTs) }\end{array}$ & 1,014 \\
\hline $\begin{array}{l}\text { Natural gas } \\
\text { (open cycle gas turbines, } \\
\text { OCGTs) }\end{array}$ & 699 \\
\hline Coal & 2,264 \\
\hline Nuclear energy (large reactors) & 4,896 \\
\hline Solar (private) & 2,297 \\
\hline Solar (commercial) & 1,696 \\
\hline Solar (large) & 1,436 \\
\hline Wind (ground-based) & 1,804 \\
\hline Wind (marine) & 4,998 \\
\hline Hydro (small) & 5,281 \\
\hline Hydro (large) & 2,493 \\
\hline Geothermal & 5,823 \\
\hline Biomass & 4,060 \\
\hline
\end{tabular}

in fact, but different capacities and do not consider other positive factors of the SMRs, which are further presented.

2. Modularity. Modularity is a main characteristic of the small modular reactors, reflected in the name of this technology. The main aspects of the SMRs modularity are the following:

factory-built (increases the quality of all components, reduces the time and costs on the construction site; along with that, does not increase the costs on arranging the reliable supply chains);

design standardization and simplification (increases the mounting effectiveness, operation and decommissioning, reduces scope of testing and maintenance;

possibility for transportation via regular railway or automobile roads (reduces risks for delayed schedule in construction, but is determined by the importance of effective project management).

Reduction of capital investments into SMRs depends on the degree of SMRs modularity and is estimated on the basis on different sources at the level from 15 to $40 \%$.

3. Possibility to expand capacity. Has a positive impact on the money flow profile during SMR construction as compared to the large reactors (receipt of income from operation of the first SMR module while continuing construction of others, reduction of investment risks, refinancing).

4. Location of several modules on one site. Reduction of costs for infrastructure during construction and operation of multi-module SMRs.

5. Cogeneration and load following (maneuvering). Possibility to use the SMRs as a balancing capacity for unstable renewable energy sector and create the hybrid systems. The issue of maneuvering capabilities of the SMRs is described in more detail in the next section of the article.

6. Learning rate. It is expected, that the reduction of capital costs while learning the SMRs technology will go faster than for the large reactors. It should be noted that cost reduction by $10 \%$ is possible to be achieved after introduction of 5-7 SMR modules.

7. Duration of construction. Due to the reduced scope of work on site, parallel manufacture of the components and performance of the greater part of tests at the production premises, it is expected that duration of SMRs construction will be possible to cut by $35 \%$ for about 2-4 years (depending on the number of constructed modules).

8. Availability. Due to the increased period between loading of the nuclear fuel from 12-24 months for NPPs up to 36-48 months for SMRs, it is possible to save the capital costs for SMRs by $2-5 \%$, and the annual expenses for maintenance by $3 \%$. Also, for some SMR designs, it will be possible to conduct refueling at one module with simultaneous operation of other modules. It is expected that the SMRs' capacity factor will be more than $95 \%$.

9. Operation costs. Due to location of several modules on one site, the operating personnel will be able to operate several modules simultaneously from one control room. It is expected that operation costs for SMRs will match the NPP's ones. The costs for fuel are estimated as being equal or lightly higher than NPPs costs.

10. Licensing time. Having in mind the most up-todate particular engineering solutions on the SMRs, the need for their experimental justification and absence of specific regulatory framework, licensing duration, have a negative impact on implementation of the SMRs related projects. It is expected, that further licensing of non-pilot (series) SMRs will proceed faster compared to NPPs.

11. Decommissioning cost. It is foreseen that due to the module-based structure of the SMRs, their decommissioning can be conducted by means of extracting the module from the site and conduct further dismantling under the factory conditions. The SMRs decommissioning costs are expected to be lower by $20 \%$ as compared to the related costs for large reactors [23].

Considering lack of the experience in practical implementation of SMRs projects, as well as commercial confidentiality of the SMRs suppliers, there are no relevant 
and justified data in public access as for the cost for the SMRs. Table 5 provided some open preliminary data with indicated references.

According to the [22], projected levelised cost of electricity for SMRs (LWR based) in 2030 are 75-125 USD/MWh.

To perform an economic evaluation and strategic planning of the power systems that will include SMRs, it is possible to apply the analytical tools of the IAEA, in particular NEST, MESSAGE and FINPLAN [26]. To fill in the methodology gap, in 2020 the IAEA has launched the coordinated research project (CRP) "Economic Appraisal of Small Modular Reactor (SMR) projects: Methodologies and Applications".

\section{Analysis of Ukrainian UPG needs and perspectives of SMR technology implementation}

At the beginning of 2020, the energy field of Ukraine entered the crisis period, referred to as the biggest one from the beginning of independence days. The cause is both unpredicted factors, specifically rapid decrease of electricity consumption due to economy decline and quarantine measures, and accumulated system miscal- culations, including drastic and in fact uncontrolled increase of solar and wind energy generation. The electricity proficit resulted in the serious consequences not only from the point of view of balancing of the energy system but also functioning of the electricity market itself.

Redistribution of the electrical generation structure and decrease of electricity consumption is illustrated in Fig. 3, where the daily consumption is compared to the electricity generation schedule as of May 22, 2019 and 2020 (data from the official site of NPC "Ukrenergo" [27]).

Comparison of the daily schedules with one-year difference $(22.05 .2019,22.05 .2020)$ demonstrates the following tendencies:

moderate decrease of electricity consumption (peak consumption in 2020 - 16.0 GW, in $2019-16.2 \mathrm{GW}$ );

considerable decrease of NPP power in daily generation $(2020$ - 7,300 MW, $2019-8,700 \mathrm{MW})$;

rapid increase of RES power in daily generation (peak load in $2020-2,600 \mathrm{MW}$, in $2019-1,200 \mathrm{MW}$ );

significant decrease of hydro power supply (hydroelectric power plant HPP, pumped hydroelectric energy storage PHES) in daily generation (peak load in 2020 1,900 MW, in $2019-2,400 \mathrm{MW})$.

Table 5. Preliminary cost characteristics of particular SMRs

\begin{tabular}{|l|c|c|c|c|c|}
\hline \multicolumn{1}{|c|}{ Economic indicator } & $\begin{array}{l}\text { NuScale [24] } \\
(12 \times 60 \mathrm{MW})\end{array}$ & $\begin{array}{l}\text { SMR-160 [25] } \\
(160 \mathrm{MW})\end{array}$ & $\begin{array}{l}\text { mPower [14, 22] } \\
(2 \times 180 \mathrm{MW})\end{array}$ & $\begin{array}{l}\text { SMART [14, 22] } \\
(330 \mathrm{MW})\end{array}$ & $\begin{array}{l}\text { Large reactors } \\
\text { (generation III+) }\end{array}$ \\
\hline Overnight capital cost, USD/kWe & USD 5,078 & - & USD 5,000 & USD 5,250 & $€ 4,000-6,000$ \\
\hline $\begin{array}{l}\text { Levelised cost of electricity (LCOE/ } \\
\text { LUEC), USD/MWh }\end{array}$ & - & - & - & USD 62 & - \\
\hline Total cost & USD 3 bln & USD 1 bln & - & - & $€ 7-10 \mathrm{bln}$ \\
\hline
\end{tabular}
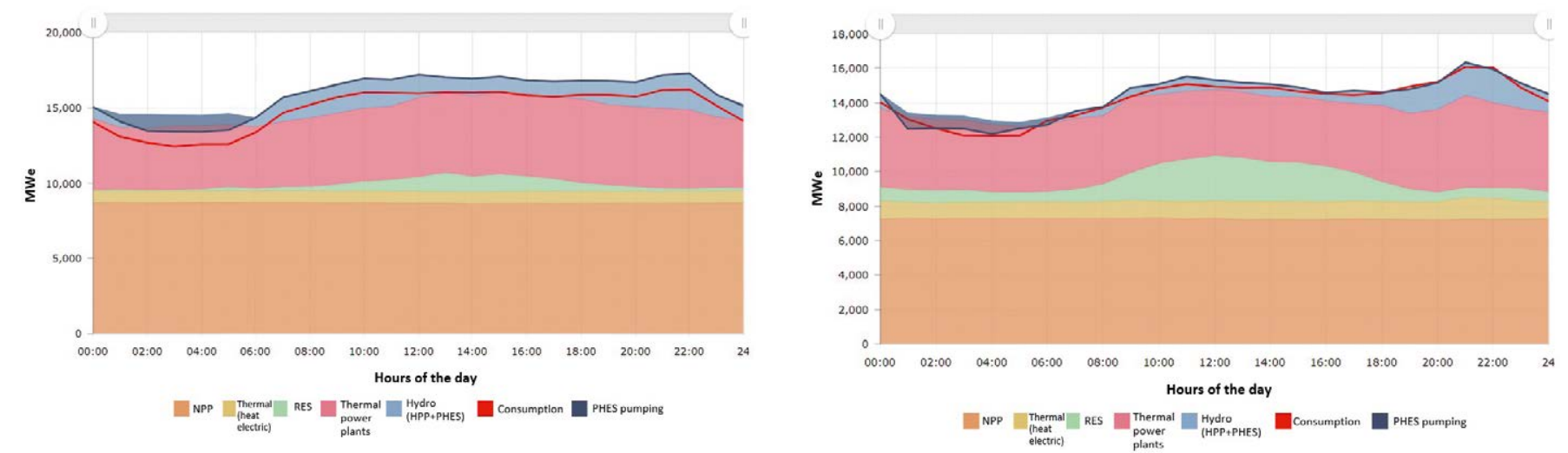

Fig. 3. Daily electricity consumption and production as of May 22, 2019 (left) and 2020 (right) (data from NPC “Ukrenergo" [27]) 


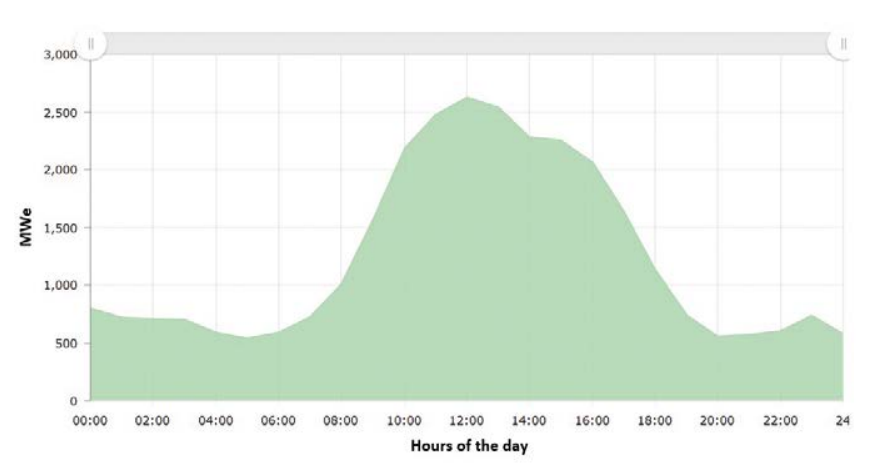

Fig. 4. RES daily electric generation/consumption as of 22.05.2020

The RES daily electric generation curve is provided in Fig. 4. A significant variability of RES electricity generation should be noted: the minimum value is $539 \mathrm{MW}$ at 5 a.m., the maximum is $2,629 \mathrm{MW}$ at 12 (noon time). With RES total capacity of 5,556,8 MW, the RES capacity factor on 22.05 .2020 changed in the range: 9.7-47.3\%. The difference in RES electricity output during a day is more than 2,000 MW, which currently is compensated by balancing of the heat and hydro generation.

The given data confirm the importance of balancing capacities in the energy system of Ukraine, which is fairly underlined in the report of NPC "Ukrenergo" [11]: "Introduction of more than $2 \mathrm{GW}$ of highly maneuvering generating capacities with quick start is needed".

The Ukrainian operating NPPs were designed for operation in the base load mode and have limited power maneuvering potential due to the thermal cycles of nuclear fuel and plant equipment, difficulties in controlling the capacity and need to perform significant amount of operations by the operating personnel, which increases the probability of human errors.

These constraints of large reactors are taken into account in SMRs at the design phase. The SMR designs foresee the engineering solutions and algorithms for power maneuvering.

The American Electric Power Research Institute (EPRI) developed the requirements to SMRs for the operators, in particular the SMR maneuvering features [28], [29]:

24-hour cycle: $100>20>100 \%$;

ramp rate of $40 \%$ per hour;

capable of automatic frequency response;

step change of $20 \%$ in 10 minutes;

frequency variation tolerance.

The NuScale design comprises several engineering solutions as regards to the quick power change, specifically by-passing module's steam generator directly to condenser for rapid responses, allow power changes by control rod movement down to $40 \%$ power, disconnection from the grid of individual modules, etc. NuScale design also considers the potential for creating the so-called hybrid systems with RES, in particular joint operation in the mode of load following with the wind stations on the site of Idaho National Laboratory (INL) [29].

In summary, the SMR integration into the Ukrainian UPG will ensure the power balancing in the energy system to compensate the daily change of RES electric generation.

The Concept of "green" energy transition of Ukraine through 2050 [12] presented by the Ministry of Energy and Environmental Protection on January 21, 2020, does not properly take into account the importance of nuclear energy field in achieving the climate objectives and ensuring the energy systems of Ukraine with balancing capacities. In accordance with the draft Concept through 2050 , it is foreseen to reduce part of the nuclear generation down to $20-25 \%$ and to increase accordingly the renewables up to $70 \%$, which is technically not feasible.

The optimal correlation between different energy sources should be defined through the results of multi-factor analysis with consideration of advantages and limitations of each type of the energy generation. This analysis should also take into account the existing results, calculation methodologies and analytical tools of the OECD/IEA and IAEA.

The OECD document [30] provides the following recommendations to the countries that consider usage of the nuclear energy, which are fully applicable for Ukraine as well:

keep the option of nuclear energy open: authorization to continue operation of the existing NPPs as long as it is safe;

acknowledge the importance of dispatching control: it is necessary to ensure acknowledgement of the role of electricity suppliers and options for dispatching control, including NPPs, and compensation of the lacking electricity generation;

acknowledge the non-market benefits: it is necessary to create equal conditions for nuclear energy with other low-carbon energy sources to acknowledge its advantages for environmental and energy security, and give it relevant preferences;

create the attractive financing infrastructure: ensure risks management and financing infrastructure, which will help to mobilize the capital for new and existing NPPs at the acceptable level, taking into account possible risks and long-term projects of nuclear energy;

provide support to the innovative projects on new nuclear reactors: acceleration of innovations in the new 
NPPs projects, such as SMR, with smaller capital investments and shorter implementation time and technologies to support integration of the increasing wind and solar energy generating capacities into the energy system;

maintain the human resources: support and development of the human resources and potential of the project management in the nuclear engineering.

\section{Summary and priority measures}

SMRs with the expected high safety and economic indicators have indubitable perspectives for introduction into the UPG of Ukraine both to compensate the existing gap of the balancing capacities, and to gradually change the heat power stations, running out of their lifetime, with the low-carbon energy sources.

Implementation of the SMR projects goes from discussions into the practical stage. In the short-term perspective (2025-2035), the pilot light-water SMR projects can be implemented, specifically NuScale, SMR-160, mPower, which currently go through licensing process by the regulatory authorities in the U.S. and Canada.

Ukraine created an effective infrastructure and gained the vast experience of NPPs operation, engineering and technical support and regulation of nuclear and radiation safety. This enables to get involved into SMRs implementation with the SMR technology suppliers on the partnership terms, and in the perspective allocate production of individual components at the manufacturing facilities of Ukraine. Considering the beneficial geographic location and rising interest in SMRs in the countries of Asia [14], Ukraine can become the site for advancing the SMR technology to the east.

The following first-priority activities are suggested for SMR implementation in Ukraine:

in-depth strategic analysis of the Ukrainian UPG using the international methodologies of the IAEA and OECD, identification of the technically and economically justified directions for further development with consideration of the general trend of transition to the low-carbon energy sources, where nuclear energy relates to as well;

identification of the Ukrainian UPG needs for balancing (maneuvering) capacities and development of technical requirements to SMRs and their maneuvering;

performance of the feasibility study for SMR construction, taking into account all factors, both positive and confining. This will include an integrated study of all stages of the SMR lifetime cycle, comprising the issues of spent fuel management and decommissioning. The analysis should be done for the design characteristics of the SMRs, which can be implemented in the short-term perspective, and the preliminary list of SMR designs for construction in Ukraine should be prepared;

development of the effective financial models for implementation of the SMR projects in Ukraine on the basis of national and private partnership.

It is also expedient to develop and get approval of the Road Map of SMR technology implementation in Ukraine on the level of the Cabinet of Ministers of Ukraine or Ministry of Energy. This road map should establish the strategic objectives, key activities and implementation period, mechanisms of the national and private financing of works, performance indicators, and responsible organizations and stakeholders involved in the implementation process.

\section{References}

1. Paris Agreement. United Nations Treaty Collection (December 12, 2015). Available at: https://treaties.un.org/pages/ViewDetails.aspx?src=TREATY\&mtdsg_no=XXVII-7-d\&chapter $=27 \&$ clang=_en

2. Transforming our world: the 2030 Agenda for Sustainable Development. United Nations - Sustainable Development knowledge platform. Available at: https://sustainabledevelopment.un.org/post2015/transformingourworld.

3. Law of Ukraine "On Ratification of Paris Climate Agreement" as of July 14, 2016, no. 1469-VIII. Available at: https://zakon.rada. gov.ua/laws/show/1469-19.

4. Decree of the President of Ukraine no. 722/2019 “On objectives of sustainable development of Ukraine through 2030". Available at: https://www.president.gov.ua/documents/7222019-29825.

5. The Costs of Decarbonisation: System Costs with High Shares of Nuclear and Renewables. OECD, NEA, 2019, 224 p. Available at: https://www.oecd-nea.org/ndd/pubs/2019/7299system-costs.pdf.

6. International Energy Agency (2016). Energy, Climate Change \& Environment - 2016 Insights. Paris: International Energy Agency, OECD/IEA. Available at: https:// www.iea.org/reports/energy-climate-change-and-environment-2016-insights.

7. Blasi A. (2020). Global energy-related $\mathrm{CO}_{2}$ emissions. International Energy Agency. Available at: https://www.linkedin. com/in/alessandro-blasi-6579a66/detail/recent-activity.

8. World Nuclear Association (2011). Comparison of lifecycle greenhouse gas emissions of various electricity generation sources. London: WNA, 12 p. Available at: http://www.world-nuclear.org/uploadedFiles/org/WNA/Publications/Working_ Group_Reports/comparison_of_lifecycle.pdf. 
9. Energoatom and Holtec Signed a Memorandum of Understanding on the Cooperation in Using Small Modular Reactors. Energoatom: official website. Available at: http://www. energoatom.kiev.ua/ua/press_centr-19.

10. MoU starts evaluation of NuScale SMR for Ukraine. World Nuclear News: official website. Available at: https:// world-nuclear-news.org/Articles/MoU-starts-evaluationof-NuScale-SMR-for-Ukraine.

11. NPC "Ukrenergo" (2020). Report on Conformance Evaluation of Generating Capacities of Ukraine. Available at: https://ua.energy/media/pres-tsentr/pres-relizy/ vzhe-u-2021-r-v-ukrayini-mayut-buduvatys-2-gvt-vysokomanevrovyh-potuzhnostej.

12. Ministry of Energy and Environmental Protection (2020). Concept of "green" energy transition of Ukraine by 2050. Available at: https://menr.gov.ua/news/34424.html.

13. Dybach A. M., Plachkov G. I. (2019). On Licensing of Small modular Reactors Technology. Nuclear and Radiation Safety, vol. 81, no. 1, pp. 3-9. DOI: 10.32918/nrs.2019.1(81).01

14. OECD/NEA (2016). Small Modular Reactors: Nuclear Energy Market Potential for Near-term Deployment. Available at: https://www.oecd-nea.org/ndd/pubs/2016/7213-smrs.pdf.

15. Bates M. (2019). Progress Updates on the SMR Program in the United States and Future Plans. IAEA TWG-SMR. Available at: https://nucleus.iaea.org/sites/htgr-kb/twg-smr/Documents/ TWG-2_2019/F01_SMR \%20- \%20TWG-SMR \%20- \%20 IAEA \%20- \%20July\%202019.pdf.

16. U.S. Department of Energy Launches $\$ 230$ Million Advanced Reactor Demonstration Program. Available at: https://www.energy.gov/ne/articles/us-department-energy-launches-230-million-advanced-reactor-demonstration-program.

17. Vaya Soler A. (2018). Overview of SMR projects worldwide, Market Potential for Near Term Deployment. Vienna: IAEA TWG-SMR, 23 p. Available at: https://nucleus.iaea.org/sites/ htgr-kb/twg-smr/Documents/TWG-1_2018/21_OECDNEA_VayaSoler_TWG_SMR_250418.pdf.

18. НП 306.2.141-2008 General provisions on NPPs safety. Available at: https://zakon.rada.gov.ua/laws/show/z0056-08\#Text.

19. Kadak A. C. (2017). A comparison of advanced nuclear technologies. Available at: https://energypolicy.columbia.edu/ sites/default/files/A \%20Comparison \%20of\%20Nuclear \%20 Technologies \%20033017.pdf

20. IAEA (2016). Advances in Small Modular Reactor Technology Developments. A Supplement to: IAEA Advanced Reactors Information System (ARIS). Available at: https://aris.iaea.org/ Publications/SMR-Book_2016.pdf

21. NuScale Power LLC (2020). Probabilistic Risk Assessment and Severe Accident Evaluation. Chapter Nineteen. PART 2 - TIER 2. Revision 4. Available at: https://www.nrc.gov/docs/ML2003/ ML20036D466.pdf.
22. OECD/NEA (2015). Projected Costs of Generating Electricity. Available at: https://www.oecd-nea.org/ndd/ pubs/2015/7057-proj-costs-electricity-2015.pdf.

23. Mignacca B., Locatelli G. (2020) Economics and finance of Small Modular Reactors: A systematic review and research agenda. Renewable and Sustainable Energy Reviews, vol. 118, 109519.

24. A cost competitive nuclear option for multiple applications. Available at: https://www.nuscalepower.com/benefits/ cost-competitive.

25. Consortium "Energoatom" and Holtec has two years to study the issue of implementation of SMR-160 in Ukraine. Available at: https://expro.com.ua/novini/konsorcum-energoatomu-ta-holtec-ma-za-2-roki-vivchiti-pitannya-dlya-vprovadjennya-reaktorv-smr-160-v-ukran.

26. Kuznetsov V., Barkatullah N. IAEA-CN-164-1S01 Approaches to Assess Competitiveness of Small and Medium Sized Reactors. Available at: https://www-pub.iaea.org/MTCD/Publications/PDF/P1500_CD_Web/htm/pdf/topic1/1S01_V.\%20 Kuznetsov.pdf.

27. NPC “Ukrenergo". Daily electricity generation/consumption curve. Available at: https://ua.energy/diyalnist/dyspetcherska-informatsiya/dobovyj-grafik-vyrobnytstva-spozhyvannya-e-e.

28. EPRI (2014). Advanced Nuclear Technology: Advanced Light Water Reactors Utility Requirements Document Small Modular Reactors Inclusion Summary. 3002003130. Final Report. Palo Alto, CA, 58 p. Available at: https://www.energy.gov/sites/prod/files/2015/12/f27/SummaryofALWRURDRev13Nov2014.pdf

29. Shropshire D. (2017). Hybrid Energy Systems. Proceedings of the Workshop on Small Modular Reactor Safety and Licensing (Hammamet, Tunisia December 12-15, 2017). Available at: https://gnssn.iaea.org/NSNI/SMRP/Shared\%20 Documents/Workshop\%2012-15\%20December\%202017/ Hybrid\%20Energy\%20Systems.pdf.

30. OECD/IEA (2019). Nuclear power in a clean energy system. Available at: https://www.iea.org/events/nuclear-power-in-a-clean-energy-system

\section{В. В. Дем'янюк}

Громадська спілка «Інститут інновацій ядерної енергетики», м. Киї, Украӥна

\section{Малі модульні реактори: безпекові та економічні показники, перспективи впровадження в} об’єднану електроенергетичну систему України 
Малі модульні реактори (ММР) $є$ перспективною технологією подальшого розвитку ядерної енергетики. У порівнянні з ядерними реакторами великої потужності (більше 700 МВт) МРР характеризуються відносно меншими капітальними інвестиціями та строком реалізації, очікувано вищими показниками безпеки, можливістю маневрування потужністю i, як наслідок, кращою відповідністю потребам енергоринку. В Україні розпочато діяльність 3 аналізу перспектив впровадження технології ММР. Інститутом інновацій ядерної енергетики налагоджена робоча співпраця з потенційними постачальниками MMP, зокрема NuScale Power (проект $\mathrm{NuScale),} \mathrm{та} \mathrm{розпочато} \mathrm{роботи} \mathrm{з} \mathrm{вивчення} \mathrm{техніко-}$ економічних аспектів MМР. У статті наведено поточний стан реалізації проектів легководних ММР у короткостроковій перспективі. Представлено якісний порівняльний аналіз різних видів електрогенерації за ключовими аспектами. Узагальнено безпекові показники MМР: частота пошкодження активної зони та частота раннього/великого аварійного викиду, розмір зони аварійного планування. Сформульовано та охарактеризовано фактори, які впливають на економічні показники ММР, зокрема потужність (до 300 МВт ел.), модульність, нарощування потужності, маневрування, освоєння технології, вартість зняття з експлуатації. На основі даних НЕК «Укренерго» представлена інформація щодо потреб Об'єднаної електроенергетичної системи (ОЕС) України у маневрових потужностях. Приділена увага поєднанню ММР і відновлюваних джерел енергії із мінливою потужністю. Сформульовано першочергові заходи для впровадження ММР в Україні, що включають в себе: 1) поглиблений стратегічний аналіз ОЕС України за міжнародними методиками (МАГАТЕ, OECD); 2) деталізацію потреб ОЕС України у балансуючих (маневрових) потужностях та розробку технічних вимог до ММР та їхньої маневреності; 3) виконання попереднього техніко-економічного обгрунтування будівництва ММР; 4) розробку ефективних фінансових моделей реалізації проектів ММР в Україні на засадах державного та приватного партнерства.

Ключові слова: малі модульні реактори, безпекові та економічні показники, об’єднана електроенергетична система, низьковуглецеві джерела енергії.

Надійшла 03.07.2020

Received 03.07.2020 